\title{
Transfer of Pseudomonas maltophilia Hugh 1981 to the Genus Xanthomonas as Xanthomonas maltophilia (Hugh 1981) comb. nov.
}

\author{
J. SWINGS, P. DE VOS, M. VAN DEN MOOTER, AND J. DE LEY* \\ Laboratorium voor Microbiologie en microbiële Genetica, Rijksuniversiteit, B-9000 Ghent, Belgium
}

\begin{abstract}
Genotypic and phenotypic data (results of deoxyribonucleic acid-ribosomal ribonucleic acid and deoxyribonucleic acid-deoxyribonucleic acid hybridizations, guanine-plus-cytosine content, comparative enzymology, type of ubiquinones, cellular fatty acid composition, growth, niches, and several other characteristics) showed that Pseudomonas maltophilia (Hugh 1981) is generically misnamed and should be transferred to Xanthomonas as Xanthomonas maltophilia (Hugh 1981) comb. nov.
\end{abstract}

An organism named "Bacterium bookerii" was isolated from pleural fluid by J. L. Edwards in 1943 in England. This strain and several similar ones were classified as Pseudomonas maltophilia by Hugh and Ryschenkow (19). The latter species name was not on the Approved Lists of Bacterial Names (29) but was revived by Hugh (16).

Strains of this species have often been associated with nosocomial infections; they have been isolated most frequently from clinical specimens, but have also been obtained from soil, water, frozen foods, and plant material.

The exact generic position of this species is not altogether clear. A number of arguments in the literature (see below) point to similarities between $P$. maltophilia and Xanthomonas; nevertheless, a definite transfer of this organism to the genus Xanthomonas was not made.

In this paper we summarize the available data in favor of the transfer of Pseudomonas maltophilia Hugh 1981 to the genus Xanthomonas as Xanthomonas maltophilia (Hugh 1981) comb. nov.

DNA-rRNA hybridizations. Deoxyribonucleic acid (DNA)-ribosomal ribonucleic acid (rRNA) hybridization techniques are very reliable for assessing taxonomic relatedness at generic and suprageneric levels $(6-8,15$; De Vos and De Ley, Int. J. Syst. Bacteriol., in press). Palleroni et al. (27) showed that the present genus Pseudomonas consists of five rRNA homology groups. For one of these, group V, $P$. maltophilia strain Stanier $67^{\mathrm{T}}$ (type strain) $\left(=\right.$ ATCC $\left.13637^{\mathrm{T}}\right)$ and three strains of its closest neighbor, Xanthomonas, were examined. More and foreign strains were required to reach a conclusion on the exact taxonomic position of $P$. maltophilia.

In an extensive survey of the genus Pseudomonas, in which a different DNA-rRNA hybrid- ization technique was used (5) and which included hundreds of strains belonging to many genera and species, De Vos and De Ley (submitted for publication) confirmed the existence of the five rRNA groups. The taxonomic distances between each pair of the five groups and their distances to other genera were determined. From Fig. 1 it appears that the five Pseudomonas groups are less related to each other than to other genera. Consequently, the generic splitting of the present genus Pseudomonas becomes unavoidable (De Vos and De Ley, in press). Figure 1 also shows that the rRNA cistrons of $P$. maltophilia are most similar to those of Xanthomonas.

DNAs from 27 strains of different Xanthomonas species displayed a thermal denaturation midpoint temperature $\left(T_{m(e)}\right)$ range of 78.8 to $81.5^{\circ} \mathrm{C}$ with reference ${ }^{14} \mathrm{C}$-labeled $23 S$ rRNA from Xanthomonas campestris pv. campestris NCPPB $528^{\mathrm{T}}$. [ $T_{m(e)}$ is the temperature at which $50 \%$ of the hybrid is denatured.] The following strains were used: $X$. campestris NCPPB $528^{\mathrm{T}}$, ICPB A121, ICPB C110, ICPB C144, ICPB C5, ICPB G1, ICPB H110, ICPB M16, ICPB P121, ICPB P137, ICPB P10, ICPB T11, ICPB L1, and ICPB V136; Xanthomonas fragariae NCPPB 1822; Xanthomonas albilineans NCPPB 2503; Xanthomonas axonopodis NCPPB $457^{\mathrm{T}}$; and Xanthomonas populi $\mathrm{Bt}_{3}$, Spm11, M1j, PC3, S8, $175,45.51$, Sma, BII, and NCPPB 2432. Four $P$. maltophilia strains (ATCC $13637^{\mathrm{T}}$, ATCC 17448, ATCC 17806, and CIP 5960) displayed $T_{m(e)}$ values of 76.5 to $78.0^{\circ} \mathrm{C}$ under the same conditions. From our extensive experience in this area $(6-8,15)$, we conclude from the $T_{m(e)}$ data that $P$. maltophilia Hugh 1981 is a member of Xanthomonas, albeit a slightly unusual one.

Guanine-plus-cytosine contents. The guanine- 


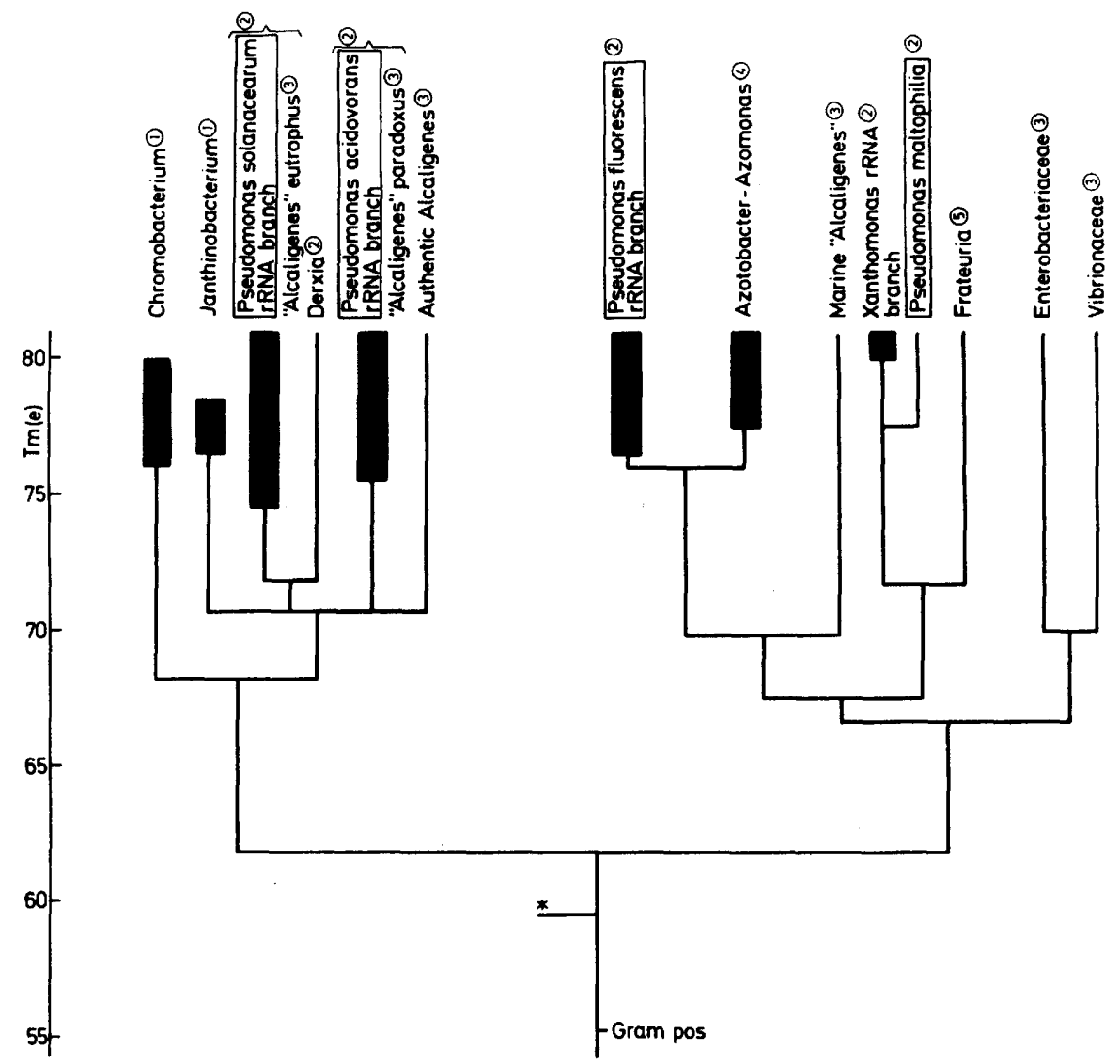

FIG. 1. rRNA cistron similarities, expressed as $T_{m(e)}$ values of DNA-rRNA hybrids (5), between different Pseudomonas groups (boxes) and a variety of other gram-negative bacteria. Not all known finer divisions of the branches are represented. Data were obtained from the following sources: 1, De Ley et al. (6); 2, De Vos and De Ley, in press; 3, De Ley et al., unpublished data; 4, De Smedt et al. (7); 5, Swings et al. (32). The asterisk indicates that Pseudomonas diminuta and Pseudomonas vesicularis are at this level, together with the Acetobacteraceae, and Rhodospirillaceae, Agrobacterium, Rhizobium, Zymomonas, and a few other organisms (8, 15; De Vos and De Ley, in press). Gram pos, Gram positive bacteria.

plus-cytosine contents that have been determined for various $P$. maltophilia strains by different authors $(20,22,24$; De Vos and De Ley, in press) range from 63 to $67.5 \mathrm{~mol} \%$ and thus fit well in the range that has been determined for Xanthomonas (63 to $70 \mathrm{~mol} \%)(4,10$; De Ley and De Vos, unpublished data). These guanine-plus-cytosine values are not inconsistent with reclassification of $P$. maltophilia into the genus Xanthomonas.

DNA-DNA homology. The DNA-DNA homologies among the three $P$. maltophilia strains and four Xanthomonas strains ( $X$. campestris pv. translucens, $X$. campestris pv. oryzae, $X$. campestris pv. pruni, and $X$. campestris pv. hyacinthi), as determined by the method of Murata and Starr (26), were very low, ranging from 4 to $15 \%$ (mean, $8.9 \%$ ); there was one exception of $21 \%$. However, the values for "Xanthomonas ampelina" (which is not a member of the genus
Xanthomonas at all) also fell in the same range. Such low values are at the border of or below the sensitivity of this method. Ikemoto et al. (20) obtained DNA homologies ranging from 37 to $100 \%$ among several $\boldsymbol{P}$. maltophilia strains and from 22 to $37 \%$ among four $P$. maltophilia strains and two members of Xanthomonas ( $X$. campestris pv. campestris and $X$. campestris pv. citri). The latter values were significantly higher than those between $P$. maltophilia and Pseudomonas aeruginosa.

Comparative enzymology. It has been suggested that alternative routes for tyrosine biosynthesis from prephenic acid via prephenate or arogenate dehydrogenases are highly conserved (2). The distribution of arogenate and prephenate dehydrogenases, the regulatory properties of these enzymes, and their cofactor specificity allowed differentiation of five groups within the genus Pseudomonas, corresponding to the five 
groups recognized by DNA-rRNA hybridization (27; De Vos and De Ley, in press). Both $P$. maltophilia and Xanthomonas are unusual in that they lack nicotinamide adenine dinucleotide phosphate-linked dehydrogenases and possess nicotinamide adenine dinucleotide-specific prephenate and arogenate dehydrogenases for tyrosine biosynthesis; the prephenate dehydrogenase is highly sensitive and the arogenate dehydrogenase is highly insensitive toward feedback inhibition by tyrosine.

There are strongly conserved control patterns for the enzyme 3-deoxy-D-arabinoheptulosonate-7-phosphate synthetase among the species of a genus (21). P. maltophilia (three strains) and Xanthomonas (six strains) both possess a group V 3-deoxy-D-arabinoheptulosonate-7-phosphate synthetase which is sensitive to sequential feedback inhibition by chorismate and has no requirement for divalent cations (34). The occurrence of this control mechanism, which is apparently unique in nature, supports a close taxonomic relationship between these two taxa.

Upon immunological comparison, the glutamine synthetases of one strain of $P$. maltophilia and two strains of Xanthomonas behaved in an identical fashion, which was distinctly different from the behavior of the enzymes of more than 30 other gram-negative organisms (1).

Ubiquinones. The structural types of isoprenoid or respiratory quinones are valuable markers for elucidating taxonomic relationships among bacterial groups (3). Both $P$. maltophilia and Xanthomonas contain ubiquinones with eight isoprene units (Q-8), whereas all other Pseudomonas strains tested generally contain ubiquinones with nine isoprene units (Q-9) as major components $(3,20)$.

Cellular fatty acid composition. Ikemoto et al. (20) showed that the cellular fatty acid composition of $P$. maltophilia is similar to that of $X$. campestris pv. campestris KS 0198 and $X$. campestris pv. citri KS 0199 but different from that of $X$. campestris pv. oryzae KS 0200 .

The patterns of the fatty acids tightly bound to other cellular compounds from Xanthomonas and $\boldsymbol{P}$. maltophilia strains are very similar and clearly distinct from those found in Pseudomonas species, members of the Enterobacteriaceae, and many other gram-negative bacteria $(25,28)$. The following branched-chain hydroxy acids occur in both Xanthomonas and $P$. maltophilia: 2-OH-9- $\mathrm{CH}_{3}$-decanoic acid, 3$\mathrm{OH}-9-\mathrm{CH}_{3}$-decanoic acid, 3-OH-11- $\mathrm{CH}_{3}$-dodecanoic acid, and $9-\mathrm{CH}_{3}$-decanoic acid. These four acids occur in the lipid $A$ component and are bound through ester and amide linkages to glucosamine residues. 9- $\mathrm{CH}_{3}$-decanoic acid and 13$\mathrm{CH}_{3}$-tetradecanoic acid are not found in several authentic Pseudomonas species. These data are not inconsistent with inclusion of $\boldsymbol{P}$. maltophilia in Xanthomonas.

Phage typing. According to Starr (31), phage typing studies have provided evidence for a relationship between $P$. maltophilia and Xanthomonas.

Growth and pigments. $P$. maltophilia cultures do not show the yellow mucoid growth typical of Xanthomonas. On medium containing $1 \%$ glucose, $0.5 \%$ yeast extract, $3 \% \mathrm{CaCO}_{3}$, and $2 \%$ agar (GYCA medium), the growth of $P$. maltophilia is nonpigmented to yellowish and shiny but not mucoid. A still-incomplete characterization of the pigments of $P$. maltophilia led to the tentative conclusion (31) that these pigments are "not xanthomonadins or at least that they are not closely related to the xanthomonadins already explored." On GYCA medium, most Xanthomonas colonies, except those of $X$. albilineans, are very mucoid due to the production of extracellular xanthan gum. When large numbers of Xanthomonas strains are inspected, it becomes clear that colony color varies broadly from white to deep yellow. Not all Xanthomonas strains show the typical bright yellow color; e.g., colonies of $X$. campestris pv. manihotis NCPPB 1834, 1161, and 2443, X. campestris pv. azadirachtae NCPPB $2388, X$. campestris pv. pedalii NCPPB 2368, $X$. campestris pv. phyllanthi NCPPB 2066, and $X$. campestris pv. ricini NCPPB 1063 are white. The colonies of a number of other Xanthomonas strains are faintly yellowish.

Some $P$. maltophilia strains characteristically form brownish grey water-soluble pigments. Brown, water-soluble pigments on GYCA medium were also formed by 5 of the 244 true Xanthomonas strains observed by us $(X$. campestris pv. bauhiniae NCPPB $1335, X$. campestris pv. laureliae NCPPB $1155, X$. campestris pv. pruni NCPPB 416, $X$. campestris pv. punicae NCPPB 466, and $X$. campestris pv. ricini NCPPB 1063). In Bergey's Manual of Determinative Bacteriology, 8th ed. (10), Xanthomonas phaseoli var. fuscans was differentiated from $X$. phaseoli $\mathrm{f}$. sp. vignicola by the production of a diffusible brown pigment. Three strains received by us as $X$. phaseoli pv. fuscans produced a brown pigment (strain Xpf from A. W. Saettler, strain PD24 from H. J. Miller, and strain HM144 from $H$. Maraite). Dye (9) doubted the stability and taxonomic utility of this character within Xanthomonas.

Niches. $P$. maltophilia is an ubiquitous bacterium. It occurs free living in nature, in animals, and in various areas of the human body, where it is sometimes associated with opportunistic infections $(13,17)$. It has been recovered from plants (e.g., the internal tissue of banana pseudostems, cotton seeds, bean pods, and tobacco 
seedlings [17]) and from rice paddies (22). At present nothing is known about the phytopathogenic capacity of $P$. maltophilia strains. However, this should not prevent the inclusion of $P$. maltophilia in the genus Xanthomonas. Whereas all known Xanthomonas strains are highly specialized plant pathogens, it is not clear whether they also occur in a free-living state. Furthermore, it would certainly not be easy to identify the specific host plant(s) for a Xanthomonas strain not isolated from diseased plants.

Hypersensitive reactions on tobacco leaves occur only with a limited number of Xanthomonas strains and appear in 1 to 4 days. The remaining Xanthomonas strains and $P$. maltophilia (five strains) cause only different degrees of chlorosis.

Other morphological, physiological, and biochemical characteristics. For phenotypic characterization of $\boldsymbol{P}$. maltophilia, we refer to the original description by Hugh and Ryschenkow (19), and to the studies of Hugh and Leifson (18), Stanier et al. (30), Gilardi (11-14), Komagata et al. (22), Hugh and Gilardi (17), and Ikemoto et al. (20). The data of these authors, together with our own unpublished data, show that $\boldsymbol{P}$. maltophilia and Xanthomonas strains share a number of characteristics, including: gram-negative rodshaped cells with polar flagella; growth in peptone broth or nutrient agar at $\mathrm{pH} 5.6$ but not at $\mathrm{pH} 4.5$; no growth in the presence of $6.5 \% \mathrm{NaCl}$; no hemolysis; acid produced oxidatively from glucose, lactose, fructose, and maltose but not from rhamnose, mannitol, ribitol, galactitol, inositol, inulin, or salicin; positive $o$-nitrophenyl- $\beta$ D-galactopyranoside reaction; oxidase negative or weak; indole, acetoin, urease, and ornithine decarboxylase are not produced; resistant to lincomycin; and hydrolysis of esculin. All $P$. maltophilia strains hydrolyze Tween 80 , but this characteristic occurs in only $82 \%$ of the 233 Xanthomonas strains examined. From the phenotypic data on P. maltophilia and Xanthomonas given by various authors, a simple matching similarity coefficient $\left(\mathrm{S}_{\mathrm{SM}}\right)$ of approximately $75 \%$ was calculated.

Reclassification of $P$. maltophilia as a new Xanthomonas species, Xanthomonas maltophilia (Hugh 1981) comb. nov. A new description of the genus Xanthomonas is being prepared as the result of a very extensive phenotypic study (Van den Mooter, Swings, and De Ley, manuscript in preparation). Our improved definition comes closest to, but is different in a number of aspects from, the description given by Dye and Lelliott (10). Our laboratory definition is that all Xanthomonas strains tested (including $P$. maltophilia and " $X$. populi," but excluding " $X$," ampelina) fall in the $T_{m(e)}$ range from 76 to $81^{\circ} \mathrm{C}$ when their DNAs are hybridized with labeled rRNA from type strain $X$. campestris pv. campestris NCPPB 528. The $T_{m(e)}$ values for all other organisms which have been tested are below $72^{\circ} \mathrm{C}$.

The arguments summarized above show that $P$. maltophilia should be transferred to the genus Xanthomonas. The inclusion of $\boldsymbol{P}$. maltophilia within one of the existing Xanthomonas species cannot be justified, as several characteristics differentiate the $\boldsymbol{P}$. maltophilia strains from all other Xanthomonas species. These strains are multitrichously flagellated, whereas Xanthomonas species have only one polarly inserted flagellum; in DNA-rRNA hybridization $P$. maltophilia strains are at the lower edge of Xanthomonas; these strains reduce nitrates to nitrites and produce lysine decarboxylase, whereas other Xanthomonas species do not; these strains do not hydrolyze starch, a characteristic found in $60 \%$ of Xanthomonas strains. $P$. maltophilia appears to be more resistant than other Xanthomonas species to antibiotics (33), dyes, and metals. All $P$. maltophilia strains are resistant to $0.01 \%$ methyl green, $0.01 \%$ thionine, and $0.01 \%$ lead acetate, whereas at least $90 \%$ of the Xanthomonas strains which have been tested are susceptible. The DNA homologies between $P$. maltophilia strains and Xanthomonas are low. All of the facts described above justify inclusion of $P$. maltophilia Hugh 1981 in the genus Xanthomonas as a separate species, Xanthomonas maltophilia (Hugh 1981) comb. nov., according to Rule 41a of the International Code of Nomenclature of Bacteria (23).

J.D.L. is indebted to the Fonds voor Kollektief Fundamenteel Onderzoek and the Instituut tot Aanmoediging van het Wetenschappelijk Onderzoek in Nijverheid en Landbouw for research and personnel grants. J.S. is indebted to the Nationaal Fonds voor Wetenschappelijk Onderzoek for a research grant, and M.V.d.M. is indebted to the Instituut tot Aanmoediging van het Wetenschappelijk Onderzoek in Nijverheid en Landbouw for a scholarship.

\section{LITERATURE CITED}

1. Baumann, L., and P. Baumann. 1978. Studies of relationship among terrestrial Pseudomonas, Alcaligenes, and enterobacteria by an immunological comparison of glutamine synthetase. Arch. Microbiol. 119:25-30.

2. Byng, G. S., R. J. Whitaker, R. L. Gherna, and R. A. Jensen. 1980. Variable enzymological patterning in tyrosine biosynthesis as a new means of determining natura relatedness among Pseudomonadaceae. J. Bacteriol. 144:247-257.

3. Collins, M. D., and D. Jones. 1981. Distribution of isoprenoid quinone structural types in bacteria and their taxonomic implications. Microbiol. Rev. 45:316-354.

4. De Ley, J. 1968. DNA base composition and hybridization in the taxonomy of phytopathogenic bacteria. Annu. Rev. Phytopathol. 6:63-90.

5. De Ley, J., and J. De Smedt. 1975. Improvements of the membrane filter method for DNA:rRNA hybridizations. Antonie van Leeuwenhoek J. Microbiol. Serol. 41:287307.

6. De Ley, J., P. Segers, and M. Gillis. 1978. Intra- and intergeneric similarities of Chromobacterium and Janthi- 
nobacterium ribosomal ribonucleic acid cistrons. Int. J. Syst. Bacteriol. 28:154-168.

7. De Smedt, J., M. Bauwens, R. Tytgat, and J. De Ley. 1980. Intra- and intergeneric similarities of ribosomal ribonucleic acid cistrons of free-living, nitrogen-fixing bacteria. Int J. Syst. Bacteriol. 30:106-122.

8. De Smedt, J., and J. De Ley. 1977. Intra- and intergeneric similarities of Agrobacterium ribosomal ribonucleic acid cistrons. Int. J. Syst. Bacteriol. 27:222-240.

9. Dye, D. W. 1962. The inadequacy of the usual determinative tests for the identification of Xanthomonas spp. N.Z. J. Sci. 5:393-416.

10. Dye, D. W., and R. A. Lelliott. 1974. Genus II. Xanthomonas, p. 243-249. In R. E. Buchanan and N. E. Gibbons (ed.), Bergey's manual of determinative bacteriology, 8 th ed. The Williams \& Wilkins Co., Baltimore.

11. Gilardi, G. L. 1971. Characterization of Pseudomonas species isolated from clinical specimens. Appl. Microbiol. 21:414-419.

12. Gilardi, G. L. 1971. Characterization of nonfermentative nonfastidious gram-negative bacteria encountered in medical bacteriology. J. Appl. Bacteriol. 34:623-644.

13. Gilardi, G. L. 1976. Pseudomonas species in clinical microbiology. Mt. Sinai J. Med. 43:710-726.

14. Gilardi, G. L. 1978. Glucose nonfermenting gram-negative bacteria in clinical microbiology. CRC Press, Inc. West Palm Beach, Fla.

15. Gillis, M., and J. De Ley. 1980. Intra- and intergeneric similarities of the ribosomal ribonucleic acid cistrons of Acetobacter and Gluconobacter. Int. J. Syst. Bacteriol. 30:7-27.

16. Hugh, R. 1981. Pseudomonas maltophilia sp. nov., nom. rev. Int. J. Syst. Bacteriol. 31:195.

17. Hugh, R., and G. L. Gilardi. 1980. Pseudomonas, p. 288 317. In E. H. Lennette, A. Balows, W. J. Hausler, Jr. and J. P. Truant (ed.), Manual of clinical microbiology, 3rd ed. American Society for Microbiology, Washington, D.C.

18. Hugh, R., and E. Leifson. 1963. A description of the type strain of Pseudomonas maltophilia. Int. Bull. Bacteriol. Nomencl. Taxon. 13:133-138.

19. Hugh, R., and E. Ryschenkow. 1961. Pseudomonas maltophilia, an Alcaligenes-like species. J. Gen. Microbiol. 26:123-132.

20. Ikemoto, S., K. Suzuki, T. Kaneko, and K. Komagata. 1980. Characterization of strains of Pseudomonas malto philia which do not require methionine. Int. J. Syst. Bacteriol. 30:437-447.

21. Jensen, R. A., D. S. Nasser, and E. W. Nester. 1967. Comparative control of a branch-point enzyme in microorganisms. J. Bacteriol. 94:1582-1593.
22. Komagata, K., E. Yabuuchi, Y. Tamagawa, and A Ohyama. 1974. Pseudomonas melanogena lizuka and Komagata 1963, a later subjective synonym of Pseudomonas maltophilia Hugh and Ryschenkow 1960. Int. J. Syst. Bacteriol. 24:242-247.

23. Lapage, S. P., P. H. A. Sneath, E. F. Lessel, V. B. D. Skerman, H. P. R. Seeliger, and W. A. Clark (ed.). 1975. International code of nomenclature of bacteria. 1976 Revision. American Society for Microbiology, Washington, D.C.

24. Mandel, M. 1966. Deoxyribonucleic acid base composition in the genus Pseudomonas. J. Gen. Microbiol. 43:273-292.

25. Moss, C. W., S. B. Samuels, J. Liddle, and R. M. McKinney. 1973. Occurrence of branched-chain hydroxy fatty acids in Pseudomonas maltophilia. J. Bacteriol. 114:10181024.

26. Murata, N., and M. P. Starr. 1973. A concept of the genus Xanthomonas and its species in the light of segmental homology of desoxyribonucleic acid. Phytopathol. $\mathrm{Z}$. $77: 285-323$

27. Palleroni, N. J., R. Kunisawa, R. Contopoulou, and $M$. Doudoroff. 1973. Nucleic acid homologies in the genus Pseudomonas. Int. J. Syst. Bacteriol. 23:333-339.

28. Rietschel, E. T., O. Lüderitz, and W. A. Volk. 1975. Nature, type of linkage, and absolute configuration of (hydroxy) fatty acid in lipolysaccharides from Xanthomonas sinensis and related strains. J. Bacteriol. 122:11801188.

29. Skerman, V. B. D., V. McGowan, and P. H. A. Sneath (ed.). 1980. Approved lists of bacterial names. Int. J. Syst. Bacteriol. 30:225-420.

30. Stanier, R. Y., N. J. Palleroni, and M. Doudoroff. 1966. The aerobic pseudomonads: a taxonomic study. J. Gen. Microbiol. 43:159-271.

31. Starr, M. P. 1981. The genus Xanthomonas, p. 742-763. In M. P. Starr, H. Stolp, H. G. Trüper, A. Balows, and H. G. Schlegel (ed.), The prokaryotes. Springer-Verlag, Berlin.

32. Swings, J., M. Gillis, K. Kersters, P. De Vos, F. Gossele, and J. De Ley. 1980. Frateuria, a new genus for "Acetobacter aurantius." Int. J. Syst. Bacteriol. 30:547-556.

33. Van den Mooter, M., J. Swings, M. De Cleene, F. Leyns, and J. De Ley. 1981. Susceptibility of Xanthomonas towards antibiotics in vitro. Meded. Fac. Landbouwwet. Rijksuniv. Gent 46:787-792.

34. Whitaker, R. J., G. S. Byng, R. L. Gherna, and R. A. Jensen. 1981. Comparative allostery of 3-deoxy-D-arabino-heptulosonate-7-phosphate synthetase as an indicator of taxonomic relatedness in pseudomonad genera. J. Bacteriol. 145:752-759. 